\section{Instrument Design May Influence Bacterial Reduction During Root Canal Preparation}

Manoel Eduardo de Lima Machado', Cleber Keiti Nabeshima', Hector Caballero-Flores ${ }^{1}$, Moyzés Elmadjian-Filho ${ }^{1}$, Marco Antônio Húngaro Duarte $^{2}$, Ronald Odinola-Zapata ${ }^{2}$, Silvana $\mathrm{Cai}^{3}$

\author{
'Department of Restorative \\ Dentistry, School of Dentistry, \\ USP - Universidade de São \\ Paulo, São Paulo, SP, Brazil \\ ${ }^{2}$ Department of Endodontics, \\ Bauru School of Dentistry, \\ USP - Universidade de São \\ Paulo, Bauru, SP, Brazil \\ ${ }^{3}$ Derpartment of Microbiology, \\ Institute of Biological Science, \\ USP - Universidade de São \\ Paulo, São Paulo, SP, Brazil
}

Correspondence: Cleber K. Nabeshima, Av. Prof. Lineu Prestes, 2227, Cidade Universitária 05508-000, São Paulo, SP, Brazil. Tel: +55-11-98224-4330. e-mail: cleberkn@hotmail.com

\section{Introduction}

The evolution of automated instrumentation has led to the development of different rotary systems which differ in several aspects, such as number of files, kinematics, design, alloy, and manufacturing process. However, a generation of rotary files has been highlighted, mainly regarding the thermal alloy treatment that results better resistance and flexibility $(1,2)$. Among them, it can mention the ProTaper Next, a new system made from NiTi M-wire that has a parallelogram shaped cross-section allowing asymmetric movements at the root canal. The Twisted File is another system, which is produced by twisting nickel-titanium wire in the R-phase and has triangular section with variable pitch along the instrument. An advantage of these two systems is the reduction of the number of files for root canal preparation, since it is possible to use only 2 or 3 files rather than 5 ones as used by conventional systems.

Although the properties of resistance and flexibility are important features of the instruments, the microbiological focus should be highlighted because it is difficult to eliminate bacteria from the root canal system (3). These microorganisms account for the development of apical periodontitis (4), with $E$. faecalis being targeted in most investigations as they are resistant to conventional endodontic treatment (5), and can survive in poor-nutrient environments (6).
Studies have demonstrated that the chemomechanical preparation using irrigating agents significantly reduce the bacterial number in the root canal (7-8), but the mechanical action of instruments accounts for more than $95 \%$ of the bacterial reduction (9-11). However, different instrument designs can affect the root canal preparation (12). Therefore, the present study evaluated the bacterial reduction promoted by ProTaper Next and Twisted File rotary systems by comparing them to ProTaper Universal and manual technique, in root canals infected with $E$. faecalis. The research hypothesis tested was that the instrument design can influence the bacterial reduction after root canal preparation. Distilled water was used as irrigant to allow the comparison only of the instruments without the influence of a chemical antibacterial.

\section{Material and Methods}

\section{Preparation of samples}

Approval for this study was obtained from the Ethical Committee of the School of Dentistry of the University of São Paulo (659.007). Sixty-eight distobuccal root canals of the maxillary molars without curvature were standardized to $12 \mathrm{~mm}$ and instrumented to a working length of $11 \mathrm{~mm}$ up to a size $15 \mathrm{~K}$-file (Dentsply Maillefer, Ballaigues, VD, Switzerland) under irrigation with distilled water. The root 
canals were filled with 17\% EDTA (Fórmula \& Ação, São Paulo, SP, Brazil) for 3 minutes to remove the smear layer and washed with $5 \mathrm{~mL}$ of distilled water. The apex was covered with composite resin (3M, Saint Paul, MN, USA), and the external root surface was sealed with epoxy resin (Araldite, Brascola, Joinvile, SC, Brazil). The specimens were fixed onto 24-well polystyrene microtiter plates by acrylic resin and sterilized by ethylene oxide (Acecil, Campinas, SP, Brazil).

\section{Contamination of Samples}

A suspension of $E$. faecalis (ATCC 29212) in tryptic soy broth (TSB; Difco, Le Pont-de-Claix, RA, France) was prepared and standardized to 4 on the McFarland scale. Sixty root canals were contaminated with the $E$. faecalis suspension by an insulin syringe. The plates were shaked (Fisher Vortex Genie 2; Fisher scientific, Bohemia, NY, USA) during 5 minutes to remove air pockets and to promote better bacterial penetration into dentinal tubules. The 8 remaining uncontaminated root canals were filled with TSB. The specimens were incubated at $37^{\circ} \mathrm{C}$ for 21 days. The root canal contents were replaced with fresh TSB every $48 \mathrm{~h}$.

After the incubation period, the root canals were filled with distilled water. Bacterial collection (S1) was carried out with three sterilized size 15 paper points (Dentsply Maillefer), which were inserted into the root canals up to working length for 1 minute each. The points were stored in tubes containing $500 \mu \mathrm{L}$ of peptone water, and serial dilutions were prepared. Different dilutions were plated in triplicate on $\mathrm{m}$-Enteroccocus agar culture medium (Difco). The plates were incubated at $37{ }^{\circ} \mathrm{C}$ for $48 \mathrm{~h}$, and the bacterial count was measured (in CFU $\mathrm{mL}^{-1}$ ).

\section{Instrumentation of Samples}

The contaminated specimens were divided into four groups $(n=15)$, as described below.

Group 1 was prepared using the ProTaper Next system (Dentsply Maillefer). The file X1 (tip size 17, .04 taper) was introduced into root canal without pressure up to working length using brushing action against walls. Then, the X2 (tip size $25, .06$ taper) was used successively exactly as described for $\mathrm{X} 1$ until the working length is passively reached. The shaping was completed using brushing action against walls.

Group 2 was prepared using the Twisted File system (SybronEndo, Orange, CA, USA). The cervical third was shaped using size 25, .08 taper file, and then, the working length was reached using a size 25, .04 taper instrument, followed by size 25, .06 taper and size 25, .08 taper instruments. The shaping was completed using brushing action against walls.

Group 3 was prepared with the ProTaper Universal system (Dentsply Maillefer). The cervical third was enlarged with the instrument sequence $\mathrm{SX}$ and $\mathrm{S} 2$. The middle and apical thirds were instrumented with S1, S2, F1, and F2 (tip size 25, .08 taper). The files were introduced into root canal without pressure up to working length using brushing action against walls.

Group 4 was prepared by crown-down manual technique. The cervical and middle thirds were enlarged with Gates-Glidden drills 1, 2 and 3, and then a size $20 \mathrm{~K}$-file was inserted gently up to working length using quarter-turn and traction movements against the walls. This movement was repeated until the instrument no longer met any resistance and the file was free in its path of penetration. These manoeuvres were subsequently repeated with size 25, 30 and $35 \mathrm{~K}$-files.

The aseptic control group consisted of 2 uncontaminated specimens instrumented according to each group, totalizing 8 uncontaminated root canals instrumented.

Irrigation during instrumentation was performed with a total of $10 \mathrm{~mL}$ of distilled water by using a syringe and a 29-gauge NaviTip (UItradent Products, South Jordan, USA), which was taken up to $3 \mathrm{~mm}$ short of the working length through an in-and-out motion for better flow. The irrigation was repeated with each exchange of an instrument.

\section{Data Collection After Instrumentation}

To determine the bacterial count (in CFU $\mathrm{mL}^{-1}$ ) immediately after instrumentation (S2), an additional $5 \mathrm{~mL}$ of distilled water was introduced after the final irrigation, filing was performed with a size 25 Hedström file, introducing it into the canal up to the working length with circumferential pulling strokes on all of the rootcanal surfaces. The file was sectioned below the handle and dropped into a tube containing $500 \mu \mathrm{L}$ of peptone water. Three sterilized size 15 paper points were inserted into the root canal for 1 minute each and were stored in the same tube as the file.

The root canals were filled with distilled water and incubated at $37{ }^{\circ} \mathrm{C}$ for 7 days. A third collection was performed in the same manner as for S2 to determine the bacterial count at 7 days after instrumentation (S3).

\section{Statistical Analysis}

Each bacterial count was log-transformed for statistical analysis. The paired t-test was used for intragroup analysis, and analysis of variance (ANOVA) with tukey test was used for intergroup analysis. The level of significance for all analysis was $p<0.05$.

\section{Results}

All the techniques were able to significantly reduce the bacterial number in the root canal at immediate and 7 days collection $(p<0.05)$. However, bacterial number was 
increased at 7 days after instrumentation using distilled water as irrigating agent $(p<0.05)$.

The comparison between groups revealed that ProTaper Next and Twisted File resulted a higher bacterial reduction than ProTaper Universal and manual technique $(p<0.05)$. However, ProTaper Next and Twisted File or ProTaper Universal and manual technique were similar ( $p>0.05$ ).

The aseptic condition during the experiment was proven by the absence of bacterial growth in uncontaminated samples.

The log CFU $\mathrm{ml}^{-1}$ of E. faecalis collection, as well as bacterial reduction at immediate and 7 days after instrumentation can be observed in Table 1.

\section{Discussion}

The instruments evolution aims to improve the shaping and cleaning ability of the root canal system with ease and practicality, and studies are necessary to confirm its purpose. This essay focused on microbiological aspect and showed that different instruments can differ on bacterial reduction of root canals infected with $E$. faecalis.

The plate culture method was used in this study because of its simplicity and efficiency $(5,7,8-11,13-19)$. Molecular methods has been highlighted because of their high sensibility to detect microorganisms, but such a feature would not be necessary in this study as there was no total absence of bacterial growth in the collection. In addition, similarity between the results in plate culture and $\mathrm{QPCR}$ has been demonstrated (7).

The manual technique was included as a control group because it has been still widely used by clinicians. The apical preparation with instruments of size $35, .02$ taper is the usual manual preparation of buccal root canals of maxillary molars. In this way, it should also be mentioned that the use of automated instruments affects the interpretation of the shaping in the apical region compared to the manual instrumentation. After the mechanical preparation, it can notice that cones of larger diameter than that of the last instrument can be used, that is, a size 25 file allows the use of cones with apical diameter up to size 35 (20). Thus, the root canal final preparation should be related on shaping promoted by automated systems rather than on that of the last instrument used $(20,21)$. In addition, previous studies reported no significant difference in bacterial reduction regarding taper and diameter $(9,10,14)$, which corroborates our findings that there was no difference between Protaper Universal with tip size 25 and manual technique using final instrument of tip size 35.

The hypothesis that the instruments design can influence the reduction of bacteria has been confirmed. Both ProTaper Next and Twisted File promoted a higher bacterial reduction than the ProTaper Universal and manual technique. The result found for the ProTaper Next is in accordance with a study by Tewari et al. (11) and Krokidis at al. (20), who also observed a better performance of this system compared to other automated systems and manual technique. The parallelogram shaped cross-section of the instrument shapes the root canal asymmetrically, with only two points of contact being present during the continuous rotation. In this way, the instrument has a larger area of escape so that a great amount of dentine can be removed coronally. The dentine compacted onto the root canal walls obstructs the dentinal tubules and this might impair the removal of bacteria from inside them. The Twisted File also showed a higher bacterial reduction than other systems, and this can be explained by the variable pitch along the instrument, which would also result in greater removal of dentin debris. Similarity between Twisted File and other systems has been observed by Ferrer Luque et al. (5) and Siqueira et al. (8) immediately post instrumentation, but the authors used instruments of larger diameter tip and/ or sodium hypochlorite during instrumentation. Despite having the greatest number of files, the ProTaper Universal system showed the lowest bacterial reduction, possibly because it has a symmetrical design and constant pitch.

The comparison between ProTaper Universal and manual technique had similar results, which is in accordance with previous studies $(9,10,14,16)$.

Although the bacterial reduction has been significant after immediate collection (S2) and on the seventh day

Table 1. Mean \pm Standard deviation (in log) of initial (S1), immediate (S2) and 7 days collection (S3) and percentage bacterial reduction

\begin{tabular}{|c|c|c|c|c|c|c|c|}
\hline Groups & $\mathrm{S} 1^{\dagger}$ & $\mathrm{S} 2^{\dagger}$ & $\mathrm{S}^{\dagger}$ & S1-S2 & $\%$ & S1-S3 & $\%$ \\
\hline ProTaper Next ${ }^{a}$ & $7.41 \pm 0.03$ & $5.62 \pm 0.28$ & $6.15 \pm 0.07$ & $7.40 \pm 0.03$ & 98.1 & $7.38 \pm 0.03$ & 94.4 \\
\hline Twisted File ${ }^{a}$ & $7.41 \pm 0.03$ & $5.46 \pm 0.27$ & $6.11 \pm 0.06$ & $7.41 \pm 0.03$ & 98.7 & $7.39 \pm 0.03$ & 94.9 \\
\hline ProTaper Universal b & $7.32 \pm 0.01$ & $6.06 \pm 0.05$ & $6.38 \pm 0.03$ & $7.30 \pm 0.02$ & 95.0 & $7.27 \pm 0.02$ & 89.0 \\
\hline Manual b & $7.31 \pm 0.01$ & $6.11 \pm 0.11$ & $6.37 \pm 0.03$ & $7.28 \pm 0.02$ & 93.4 & $7.26 \pm 0.01$ & 88.5 \\
\hline
\end{tabular}

†Same superscript symbol means significant difference. Paired t-test $(\mathrm{p}<0.05)$; ${ }^{\mathrm{a}-\mathrm{b} S a m e}$ superscript letter means no significant difference in both bacterial reductions. ANOVA test $(\mathrm{p}<0.05)$. 
(S3), the comparison between S2 and S3 had significant bacterial growth, which is in accordance with the literature using distilled water or saline solution $(9,13,15)$. In fact, $E$. faecalis can survive to instrumentation and poor-nutrient environments (6), as no nutrition was used within this interval, thus allowing re-colonization of the root canal (9). This fact demonstrates the importance of an intracanal medicament between the appointments (4). Furthermore, distilled water was used as irrigant because the mechanical action of the instruments can only be evaluated without the influence of any antimicrobial chemical substance. In this, Bortoluzzi et al. (18) demonstrated that antimicrobials irrigants are confounding factor on bacterial reduction. However, it is known that the endodontic treatment is performed in association with chemical substances, which are aimed to assist instrumentation and enhance disinfection $(5,13,15,22)$. Previous studies $(17,22)$ observed that chemical substances used as irrigant have antimicrobial activity and reduce the bacterial number in the root canal, while other authors (23) confirmed that sodium hypochlorite penetrates into dentinal tubules, and found that bacteria on root canal surface and dentinal tubules were significantly reduced when the antimicrobial agents were used (18). Moreover, bacterial remaining was found at S2 and S3 collection, the chemical substances could reduce the bacterial amount. Other studies demonstrated that substances such sodium hypochlorite and chlorhexidine can reduce the bacterial count to zero or almost zero at immediate collection $(13,15,16)$. In addition, activated irrigation may be an important factor in the cleaning of the root canal $(24,25)$. Therefore, further studies using chemical substances and different irrigation protocols should be considered.

It can be concluded that ProTaper Next and Twisted File promote a higher bacterial reduction than Protaper Universal and manual technique in infected canal roots. The instrument design appears to influence the bacterial reduction after root canal preparation.

\section{Resumo}

A proposta deste estudo foi avaliar a redução bacteriana promovida pelos sistemas ProTaper Next e Twisted File comparando-os ao sistema ProTaper Universal e técnica manual. Sessenta raizes disto vestibulares de molares superiores esterilizadas com óxido de etileno foram contaminadas com Enterococcus faecalis. Após incubação por 21 dias, amostras foram coletas e cultivadas em $\mathrm{m}$-Enterococcus agar. Os canais foram divididos em 4 grupos de acordo com o sistema de instrumentação: ProTaper Next, Twisted File, ProTaper Universal, e técnica manual crown-down. Outros 8 canais não contaminados foram utilizados como controle de assepsia. Amostra bacteriana foi coletada imediatamente após o prepare e aos 7 dias. A redução bacteriana foi calculada, e então feita a análise intergrupos utilizando teste t-pareado, e análise entre grupos utilizando os testes ANOVA e Tukey, todos com 5\% de significância. Todas as técnicas reduziram significantemente o número de bactérias no canal radicular $(p<0.05)$. ProTaper Next e Twisted File resultaram em maior redução bacteriana que ProTaper Universal e técnica manual $(p<0.05)$. ProTaper Next e Twisted File foram semelhantes $(p>0.05)$. Pode-se concluir que ProTaper Next e Twisted File promovem maior redução bacteriana que Protaper Universal e técnica manual.

\section{Acknowledgements}

The authors thank Acecil for ethylene oxide sterilization.

\section{References}

1. Pereira ES, Viana AC, Buono VT, Peters OA, Bahia MG. Behavior of nickel-titanium instruments manufactured with different thermal treatments. J Endod 2012;41:67-71.

2. Uygun AD, Kol E, Topcu MK, Seckin F, Ersoy I, Tanriver M. Variations in cyclic fatigue resistance among ProTaper Gold, ProTaper Next and ProTaper Universal instruments at different levels. Int Endod J 2016;49:494-499.

3. Vera J, Siqueira JF Jr, Ricucci D, Loghin S, Fernández N, Flores B, Cruz AG. One- versus two-visit endodontic treatment of teeth with apical periodontitis: a histobacteriologic study. J Endod 2012;38:1040-1052.

4. Kakeshasi S, Stanley HR, Fitzgerald RJ. The effects of surgical exposures of dental pulps in germ-free and conventional laboratory rats. Oral Surg Oral Med Oral Pathol 1965;20:340-349.

5. Ferrer-Luque CM, Bejarano I, Ruiz-Linares M, Baca P. Reduction in Enterococcus faecalis counts - a comparison between rotary and reciprocating systems. Int Endod J 2014;47:380-386.

6. Sedgley CM, Lennan SL, Appelbe OK. Survival of Enterococcus faecalis in root canals ex vivo. Int Endod J 2005;38:735-742.

7. Alves FRF, Rôças IN, Almeida BM, Neves MAS, Zoffoli J, Siqueira JF Jr. Quantitative molecular and culture analyses of bacterial elimination in oval-shaped root canals by a single-file instrumentation technique. Int Endod J 2012;45:871-877.

8. Siqueira JF Jr, Alves FRF, Versiani MA, Rôças IN, Almeida BM, Neves MAS, Souza-Neto MD. Correlative bacteriologic and micro-computed tomographic analysis of mandibular molar mesial canals prepared by self-adjusting file, reciproc, and twisted-file systems. J Endod 2013;39:1044-1050.

9. Machado MEL, Nabeshima CK, Leonardo MFP, Reis FAZ, Britto MLB, Cai $\mathrm{S}$. Influence of reciprocating single-file and rotary instrumentation on bacterial reduction on infected root canals. Int Endod J 2013;46:10831087.

10. Nabeshima CK, Caballero-Flores H, Cai S, Aranguren J, Borges Britto $\mathrm{ML}$, Machado ME. Bacterial removal promoted by 2 single-file systems: Wave One and One Shape. J Endod 2014; 40:1995-1998.

11. Tewari RK, Ali S, Mishra SK, Kumar A, Andrabi SM, Zoya A, Alam $S$. Mechanical reduction of the intracanal Enterococcus faecalis population by Hyflex CM, K3XF, ProTaper Next, and two manual instrument systems: an in vitro comparative study. J Investig Clin Dent 2016;7:168-173.

12. Zhao D, Shen $Y$, Peng B, Haapasalo M. Root canal preparation of mandibular molars with 3 nickel-titanium rotary instruments: a microcomputed tomographic study. J Endod 2014;40:1860-1864.

13. Dametto FR, Ferraz CCR, Gomes BPFA, Zaia AA, Teixeira FB, Souza-Filho FJ. In vitro assessment of the immediate and prolonged antimicrobial action of chlorhexidine gel as an endodontic irrigant against Enterococcus faecalis. Oral Surg Oral Med Oral Pathol Oral Radiol Endod 2005;99:768-772.

14. Machado MEL, Sapia LAB, Cai S, Martins GHR, Nabeshima CK. Comparison of two rotary systems in root canal preparation regarding disinfection. J Endod 2010;36:1238-1240.

15. Dornelles-Morgental $R$, Guerreiro-Tanomaru JM, Faria-Júnior NB, Hungaro-Duarte MA, Kuga MC, Tanomaru-Filho M. Antibacterial efficacy of endodontic irrigating solutions and their combinations in root canals contaminated with Enterococcus faecalis. Oral Surg Oral Med Oral Pathol Oral Radiol Endod 2011;112:396-400.

16. Nakamura VC, Cai S, Candeiro GTM, Ferrari PH, Caldeira CL, Gavini $\mathrm{G}$, Ex vivo evaluation of the effects of several root canal preparation techniques and irrigation regimens on a mixed microbial infection. Int 
End J 2013;16:217-224.

17. Guerreiro-Tanomaru JM, Chávez-Andrade GM, Faria-Júnior NB,

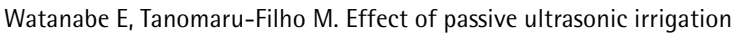
on Enterococcus faecalis from root canals: An ex vivo study. Braz Dent J 2015;26:342-346.

18. Bortoluzzi EA, Carlos Jr D, Meghil MM, El-Awady AR, Niu L, Bergeron

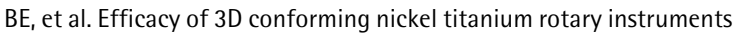
in eliminating canal wall bacteria from oval-shaped root canals. J Dent 2015;43:597-604.

19. Krokidis A, Bonfanti C, Cerutti A, Barabanti N, Zinelis S, Panopoulos P. Comparative analysis of SAF, ProtaperNext and BT-Race in eliminating Enterococcus faecalis from long oval canals: An ex vivo study. Aust Endod J 2016 [Epub ahead of print]. doi: 10.1111/aej.12177.

20. Nabeshima CK, Martins GHR, Leonardo MFP, Shin RCF, Cai S, Machado MEL. Comparison of three techniques with regard to bacterial leakage. Braz J Oral Sci 2013;12:212-215.

21. Jeon HJ, Paranjpe A, Ha JH, Kim E, Lee W, Kim HC. Apical enlargement according to different pecking times at working length using reciprocating files. J Endod 2014;40:281-284.
22. Cohenca N, Silva LAB, Silva RAB, Nelson-Filho P, Heilborn $C$, Watanabe $E_{1}$ et al. Microbiological evaluation of different irrigation protocols on root canal disinfection in teeth with apical periodontitis: An in vivo study. Braz Dent J 2013;24:467-473.

23. Zou L, Shen Y, Li W, Haapasalo M. Penetration of sodium hypochlorite into dentin. J Endod 2010;36:793-796.

24. Blank-Gonçalves LM, Nabeshima CK, Martins GHR, Machado MEL. Qualitative analysis of the removal of the smear layer in the apical third of curved roots: Conventional irrigation versus activation systems. J Endod 2011;37:1268-1271.

25. Ordinola-Zapata $\mathrm{R}$, Bramante $\mathrm{CM}$, Aprecio RM, Handysides $\mathrm{R}$, Jaramillo DE. Biofilm removal by $6 \%$ sodium hypochlorite activated by different irrigation techniques. Int Endod J 2014;47:659-666.

Received January 24, 2017 Accepted June 20, 2017 